\title{
UJI AKTIVITAS TANIN DAUN MIMBA (Azzadirachta indica) TERHADAP BAKTERI Salmonella typhi
}

\author{
Derys Ruwandha, Dwi Fitri Yani*, Damayanti Iskandar \\ Program Studi Kimia, Fakultas Sains dan Teknologi \\ Universitas Islam Negeri Raden Fatah Palembang, JL.Prof. K.H. Zainal Abidin Fikri Palembang, 30126 \\ *Email: dwifitriyani_uin@radenfatah.ac.id
}

Received 19 January 2021

Accepted 4 June 2021

\begin{abstract}
ABSTRAK
Penyakit tipus adalah penyakit yang disebabkan oleh bakteri gram negatif yaitu Salmonella typhi, salah satu pengobatan terhadap penyakit tipus adalah pengobatan dari bahan alam yang mengandung senyawa metabolit sekunder, yang diketahui dapat menghambat pertumbuhan bakteri. Tujuan penelitian ini adalah untuk mengetahui aktivitas antibakteri senyawa tanin daun mimba (Azzadirachta indica) terhadap bakteri Salmonella Typhi dengan menggunakan metode difusi cakram. Uji aktivitas antibakteri ditentukan berdasarkan diameter daya hambat senyawa tanin terhadap bakteri Salmonella typhi. Uji Fitokimia Ekstrak metanol daun mimba positif mengandung tanin, flavonoid, alkaloid, steroid, dan saponin. Pemisahan senyawa tanin dari ekstrak metanol menghasilkan nilai rendemen sebesar $69.6 \%$. Hasil pengujian antibakteri senyawa tanin dapat menghambat bakteri Salmonella typhi berturut-turut pada konsentrasi 15\% (b/v), 30\% (b/v), 50\% (b/v), dan 75\% (b/v) yaitu sebesar 15.03, 16.78, 19.02, 21.78 mm dengan klasifikasi kuat sampai sangat kuat berdasarkan klasifikasi Davis \& Stout.
\end{abstract}

Kata Kunci : Daun Mimba, Antibakteri, Salmonella typhi, Tanin.

\begin{abstract}
Typhoid is a disease caused by gram-negative bacteria, namely Salmonella typhi, one of the treatments for typhoid is a treatment made from natural ingredients that contain secondary metabolites, which are known to inhibit bacterial growth. The purpose of this study was to determine the antibacterial activity of the tannin compound of neem leaves (Azzadirachta indica) against Salmonella typhi using the disc diffusion method. The antibacterial activity test was determined based on the diameter of the inhibition of tannins against Salmonella typhi. Phytochemical Test The methanol extract of neem leaves was positive for tannins, flavonoids, alkaloids, steroids, and saponins. Separation of tannin compounds from methanol extract resulted in a yield value of $69.6 \%$. The results of the tannin compound antibacterial test can inhibit Salmonella typhi bacteria at a concentration of $15 \%(\mathrm{~b} / \mathrm{v}), 30 \%(\mathrm{~b} / \mathrm{v}), 50 \%(\mathrm{~b} / \mathrm{v})$, and $75 \%(\mathrm{~b} / \mathrm{v})$ respectively, namely $15.03,16.78$, $19.02,21.78 \mathrm{~mm}$ with a strong to very strong classification based on the Davis \& Stout classification.
\end{abstract}

Keyword: Neem Leaves, Antibacterial, Salmonella Typhi, Tannin 


\section{Pendahuluan}

Indonesia merupakan negara berkembang yang kaya akan keanekaragaman hayati karena merupakan negara tropis yang memiliki jenis-jenis tumbuhan berkhasiat melimpah (Moeloek, F. A. 2006), Salah satu tumbuhan yang dimanfaatkan masyarakat sebagai obat adalah tanaman mimba (Azzadirachta indica).

Tanaman mimba (Azzadirachta indica) banyak tumbuh di dataran rendah yang beriklim tropis maupun sub tropis (Sugiharjo, 2007). Hasil skrinning fitokimia dan spektrofotometer infra merah daun mimba mengandung senyawa metabolit sekunder sebagai antibakteri karena memberikan hasil uji positif pada senyawa tanin, triterpene, saponin, alkaloid, flavonoid, dan steroid. (Dyah, et al., 2016), (Rohma, 2011). Menurut Mihra et al.,(2018) kadar tanin didalam ekstrak etanol dan air daun mimba (Azzadirachta indica) adalah sebesar $0.55 \%$ dan $0.27 \%$ pada $50 \mathrm{~g}$ sampel. Tanin adalah suatu polifenol yang memiliki berat molekul yang besar dan terdiri dari gugus karboksil dan hidroksi (Hovart, 1981)

Tanin dapat berpotensi menghambat pertumbuhan bakteri Salmonella Tyhpi penyebab penyakit demam tifoid atau tipus (Erni, 2004). Tifoid atau yang sering disebut tipus adalah penyakit yang disebabkan oleh aktivitas suatu bakteri yaitu Salmonella typhi. Diperkirakan terdapat sejumlah 600.000-1.500.000 per-tahun penyakit tifoid yang menyebabkan kematian lebih dari 3\% dari seluruh kematian di Indonesia (Tri Atmojo dan Triningsih, 1998).

Pengobatan terhadap penyakit tipus masih menjadi masalah utama karena penggunaan obat-obatan sintetik terkadang memberikan efek samping terhadap tubuh, sehingga diperlukan alternatif pengobatan dari bahan alam yang mengandung senyawa metabolit sekunder. Menurut Erni (2004), tanin mampu menghambat pertumbuhan bakteri Salmonella Typhii (Mihra et al., 2018). Data penelitian tanin dari Putu et al.,(2015) bahwa, senyawa tanin yang dihasilkan pada daun trembesi (Samanea saman (Jacq.) Merr) mampu menghambat aktivitas suatu bakteri sebesar $7.0 \mathrm{~mm}$ pada konsentrasi $6 \%$.

\section{Metode Penelitian}

Waktu dan Tempat Pelaksanaan

Penelitian ini dilaksanakan pada bulan Februari - Agustus 2020 di Laboratorium Universitas Islam Negeri Raden Fatah Palembang dan Balai Besar Lingkungan Hidup (BBLK) Palembang Sumatera Selatan.

\section{Alat dan Bahan}

Alat gelas, corong pisah statif dan klem, pengaduk kaca, tabung reaksi, erlenmeyer, toples, neraca analitik (OHAUS PA224), pipet tetes, rotary evaporator (Yamato RE301C-W), autoklaf (GEA LS-50LJ), Inkubator (Memmert IN750 plus), aluminium foil, kaca arloji, kertas saring, cawan petri, spatula, bunsen, hot plate, corong, erlenmeyer, dan kertas cakram.

Daun mimba (Azzadirachta indica) yang diambil di daerah Sekip Palembang Sumatera Selatan, Metanol, Etil asetat, dan N-heksana, reagen Meyer dan Dragendorff, aquadest, $\mathrm{HCl}$, serbuk Nutrient agar, paper disc, DMSO, amoxcillin $4.0 \%, \mathrm{Mg}, \mathrm{FeCl}_{3}$, larutan asam asetat anhidrat, $\mathrm{H}_{2} \mathrm{SO}_{4}$ pekat, dan bakteri Salmonella thypi.

Prosedur Penelitian

Preparasi Dan Maserasi

Daun mimba dikeringkan, Serbuk daun mimba disaring untuk menghilangkan pengotor, sebanyak 590 g dilakukan maserasi dengan metanol selama 24 jam sebanyak 3 kali, 
kemudian pelarutnya diuapkan dengan rotary evaporator dan dihitung rendemen nya.

\section{Uji Fitokimia}

Uji Tanin (Dewi, 2013)

Ekstrak daun mimba ditambahkan 4 tetes larutan Ferric chloride $\left(\mathrm{FeCl}_{3}\right)$ pada $1 \mathrm{ml}$ ekstrak daun mimba, dan ditunggu hasilnya apabila terbentuk warna hijau atau biru kehitaman maka menunjukkan adanya senyawa tanin.

\section{Uji Alkaloid (Dewi, 2013)}

Reagent Dragendorff (Potassium Bismuth Iodide) ditambahkan $1 \mathrm{ml}$ pada $1 \mathrm{ml}$ ekstrak daun mimba, apabila terbentuk endapan merah bata maka positif alkaloid.

Uji Flavonoid (Dewi, 2013)

Ditambahkan $1 \mathrm{ml} \mathrm{HCl}, \mathrm{Mg}$, dan etanol pada $1 \mathrm{ml}$ ekstrak daun mimba. Apabila terjadinya perubahan warna menjadi merah atau jingga maka positif flavonoid.

Uji Steroid dan Triterpenoid (Dewi, 2013)

Ditambahkan $\mathrm{H}_{2} \mathrm{SO}_{4}$ pekat dan asam asetat anhidrat sebanyak $1 \mathrm{ml}$ pada $1 \mathrm{ml}$ ekstrak daun mimba, apabila ekstrak berubah warna menjadi hijau atau biru maka sampel tersebut mengandung senyawa steroid, dan apabila ekstrak berubah warna menjadi ungu atau jingga maka positif triterpenoid.

\section{Uji Saponin (Dewi, 2013)}

Uji saponin dilakukan dengan cara Foam's Test. $1 \mathrm{ml}$ ekstrak dimasukkan kedalam tabung reaksi dan ditambahkan aquadest dan dikocok sebanyak 10 kali dan apabila terbentuk busa setinggi 1-10 $\mathrm{cm}$ maka positif saponin.

\section{Pemisahan Tanin}

Total ekstrak pekat daun mimba ditambahkan dengan metanol : aquadest (1:1). Dan didiamkan selama 24 jam untuk memisahkan klorofil dan tanin yang terdapat pada ekstrak, selanjutnya filtrat disaring, sehingga diperoleh endapan. Endapan yang berada di bagian dasar adalah klorofil yang tidak dibutuhkan dalam pengujian sedangkan yang berbentuk koloid yang mengambang di permukaan (Gummy) adalah tanin. Filtrat dan etil asetat dimasukkan ke dalam corong pisah dengan perbandingan 1:1 hingga terbentuk 2, kemudian fase bawah di pisahkan, selanjutnya fase methanol-air ditambahkan pelarut n-heksan 1:1 dan dipisahkan. Masing-masing fraksi yang diperoleh dihitung rendemennya dan dilakukan uji fitikokimia kembali untuk memastikan adanya senyawa tanin dalam sampel yang akan diuji.

Uji Antibakteri

Uji aktivitas antibakteri menggunakan metode diameter daya hambat dengan kontrol positif yaitu Amoxcillin 4\%, dan kontrol negatif yaitu aquadest.

\section{Sterilisasi Alat}

Sebelum memasukkan larutan NA, cawan petri dan alat-alat disterilkan terlebih dahulu menggunakan autoclaff pada suhu $100^{\circ} \mathrm{C}$.

Pembuatan media agar

Aquadest dimasukkan ke dalam erlenmeyer sebanyak $200 \mathrm{ml}$, panaskan menggunakan hotplate stirrer, masukkan $0.2 \mathrm{~g}$ serbuk NA ke dalam Erlenmeyer dan homogenkan dengan menggunakan magnetic stirrer, setelah homogen tutup bagian atas Erlenmeyer dengan menggunakan kapas dan alluminium foil dan diamkan beberapa saat sampai mengeras.

\section{Inokulasi Bakteri}

Salmonella Typi diinokulasikan pada media agar dengan cara, cawan petri dibagi menjadi 6 bagian, kontrol positif berupa Ammoxcillin 4\%, kontrol negatif berupa aquadest, sampel tanin dengan beberapa konsentrasi. Jarum ose yang telah dipanaskan digunakan untuk mengambil biakan Salmonella thypi dan diinokulasikan pada seluruh bagian 
media agar dengan metode zig-zag secara vertikal. Cawan petri yang sudah diinokulasikan bakteri diinkubasi selama 48 jam pada suhu $37^{\circ} \mathrm{C}$.

Pengaplikasian sampel

Media agar yang diinokulasikan bakteri Salmonella Typi yang telah disterilkan dan diinkubasi pada setiap cawan petri disesuaikan dengan variasi konsentrasi ekstrak yaitu 15\%, 30\%, $50 \%, 75 \%$ yang telah dilarutkan dengan larutan DMSO. Kemudian kertas cakram direndam pada setiap variasi konsentrasi ekstrak daun mimba (Azzadirachta Indica). Setelah itu media agar diinkubasi kembali pada suhu $37^{\circ} \mathrm{C}$ selama 24 jam.
Preparasi dan Ekstraksi Sampel

Daun mimba dicuci dan dikeringkan. Pengeringan daun mimba dilakukan untuk mengurangi kadar air sehingga terhindar dari jamur, selain itu juga untuk mendapatkan simplisia yang tidak mudah rusak sehingga dapat disimpan dalam jangka waktu yang lama (Susmitha et al., 2013).

Ekstrak kental daun mimba yang sudah di evaporator memiliki berat sebesar $33 \mathrm{~g}$ sehingga didapatkan rendemen sebesar $5.59 \%$.

\section{Uji Fitokimia Ekstrak Daun Mimba}

Berikut merupakan tabel dari uji fitokimia ekstrak daun mimba yang telah dilakukan :

\section{Hasil dan Pembahasan}

Tabel 1. Kandungan fitokimia ekstrak metanol dan fraksi tanin

\begin{tabular}{c|c|c}
\hline \multirow{2}{*}{ Uji } & \multicolumn{2}{c}{ Hasil Uji } \\
\cline { 2 - 3 } & Ekstrak Metanol & Fraksi Tanin \\
\hline Flavonoid & $(+)$ & $(-)$ \\
& Berwarna Jingga & Berwarna Hijau \\
\hline Terpenoid & $(-)$ & $(-)$ \\
& Berwarna Hijau & Berwarna Hijau \\
\hline Tanin & $(+)$ & $(+)$ \\
& Hijau Kehitaman & Hijau Kehitaman \\
\hline Steroid & $(+)$ & $(-)$ \\
& Berwarna Coklat & Berwarna Hijau \\
\hline Saponin & $(+)$ & $(-)$ \\
& Terbentuk Busa & Tidak Terbentuk Busa \\
\hline Alkaloid & $(+)$ & $(-)$ \\
& Berwarna Kuning Endapan & Berwarna Kuning Tidak \\
& Putih & Terdapat Endapan Putih \\
\hline
\end{tabular}

Hasil uji fitokimia yang dilakukan pada ekstrak daun mimba menunjukkan bahwa ekstrak daun mimba (Azzadirachta indica) positif mengandung tanin, flavonoid, alkaloid, saponin, dan steroid. Hasil uji fitokimia tersebut berbeda dengan penelitian Mihra (2018) yang positif mengandung terpenoid (Dyah et al., 2016)(Rohma, 2011). Sedangkan uji fitokimia pada Tabel 1 uji negatif untuk terpenoid hal ini disebabkan adanya perbedaan lokasi tumbuh, sehingga mengakibatkan perbedaan senyawa yang terbentuk. Perbedaan hasil uji fitokimia tersebut juga dikarenakan pengaruh usia tanaman dan faktor genetik, temperatur, cuaca, curah hujan, keadaan tanah, dan nutrisi yang diberikan (Senja, 2014)

Hasil uji fitokimia pada fraksi tanin menunjukkan bahwa positif mengandung tanin yang ditunjukkan 
dengan perubahan warna menjadi hijau dengan uji $\mathrm{FeCl}_{3}$ dan terdapat endapan putih dengan penambahan larutan gelatin. Tanin telah terpisah dengan senyawa lain yang terdapat pada ekstrak daun mimba. Hal ini disebabkan karena tanin dapat membentuk koloid dengan air dan akan terpisah dengan endapan larutan dikarenakan senyawa tanin dapat larut di dalam air.

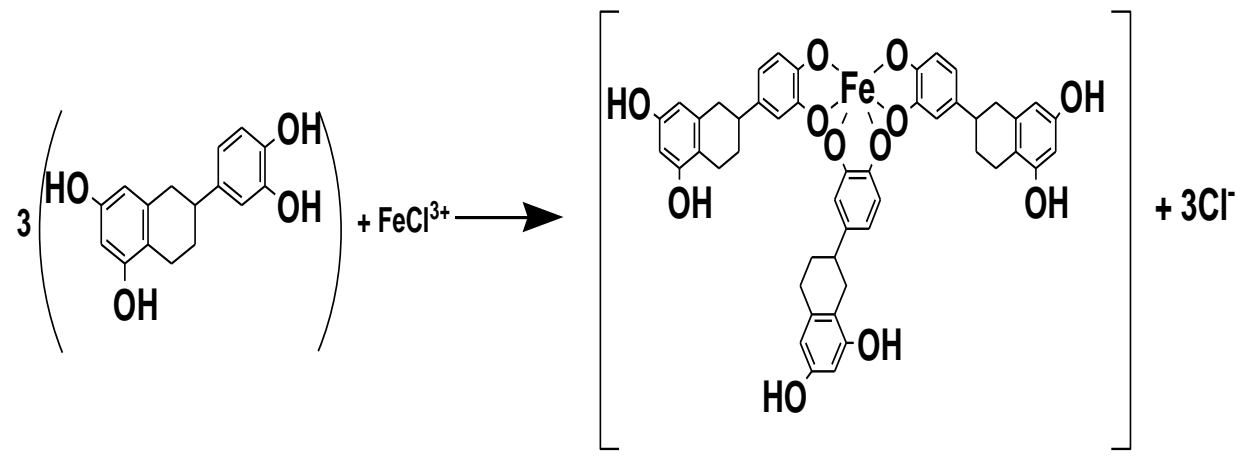

\section{Pemisahan Tanin}

Gambar 1. Reaksi Tanin $+\mathrm{FeCl}_{3}$
Berdasarkan penelitian Erni (2004), senyawa tanin yang telah disintesis menjadi asam tanat yang sudah diperjual-belikan memberikan pengaruh yang sangat bermakna terhadap bakteri Salmonella Typhi yang lebih baik dibandingkan dengan kontrol positif berupa kloramfenikol (Erni, 2004), sehingga pada penelitian ini dilakukan pemisahan senyawa tanin terhadap senyawa-senyawa lain yang terdapat pada daun mimba, untuk mengetahui daya hambat terhadap bakteri Salmonella typhi.

Fraksi tanin air berwarna hitam menghasilkan rendemen paling banyak sebesar $69 \%$, fraksi etil asetat berwarna kuning menghasilkan rendemen sebesar $9.1 \%$, dan fraksi n-heksana berwarna orange kehitaman, menghasilkan rendemen paling sedikit sebesar 3.6\%. Senyawa tanin dapat terpisah karena tanin akan membentuk koloid dengan air dan terpisah dengan endapan dikarenakan senyawa tanin dapat larut didalamnya, setelah itu difraksinasi caircair dengan pelarut etil asetat dan nheksana yang akan memisahkan senyawa berdasarkan kepolarannya, data partisi dan rendemen pemisahan tanin dirangkum pada Tabel 2.

Tabel 2. Hasil Partisi Dan Rendemen

\begin{tabular}{c|c|c}
\hline Pelarut & Warna Ekstrak Pekat & Rendemen (\%) \\
\hline Fraksi Tanin Air & Hitam & $69.6 \%$ \\
\hline Fraksi EtilAsetat & Kuning & $9.1 \%$ \\
\hline Fraksi NHeksana & Oranye Kehitaman & $3.6 \%$ \\
\hline
\end{tabular}

\section{Uji Antibakteri}

Metode yang digunakan dalam penelitian ini adalah difusi cakram. Difusi cakram merupakan salah satu metode uji aktivitas antibakteri yang paling banyak digunakan dikarenakan penggunaannya yang mudah dan sederhana (Guyton, 2007). Berikut merupakan tabel dari uji antibakteri 
senyawa tanin dan ekstrak daun mimba yang telah dilakukan :

Tabel 3. Uji Antibakteri Senyawa Tanin Daun Mimba

\begin{tabular}{|c|c|c|c|c|c|}
\hline \multirow[t]{2}{*}{ Konsentrasi } & \multicolumn{4}{|c|}{ Diameter Daya Hambat (mm) } & \multirow{2}{*}{$\begin{array}{c}\text { Rata-Rata Zona } \\
\text { Hambat (mm) }\end{array}$} \\
\hline & 1 & 2 & 3 & 4 & \\
\hline $15 \%$ & 14.04 & 14.04 & 16.03 & 16.02 & 15.03 \\
\hline $30 \%$ & 16.05 & 17.03 & 17.03 & 17.02 & 16.78 \\
\hline $50 \%$ & 20.01 & 18.02 & 19.02 & 19.04 & 19.02 \\
\hline $75 \%$ & 22.04 & 21.07 & 22.01 & 22.02 & 21.78 \\
\hline $\begin{array}{c}\text { Kontrol (+) } \\
\text { Ammoxcilin } 4.0 \%\end{array}$ & 26.02 & 28.01 & 30.02 & 28.07 & 28.02 \\
\hline $\begin{array}{l}\text { Kontrol (-) } \\
\text { Aquadest }\end{array}$ & 0 & 0 & 0 & 0 & 0 \\
\hline
\end{tabular}
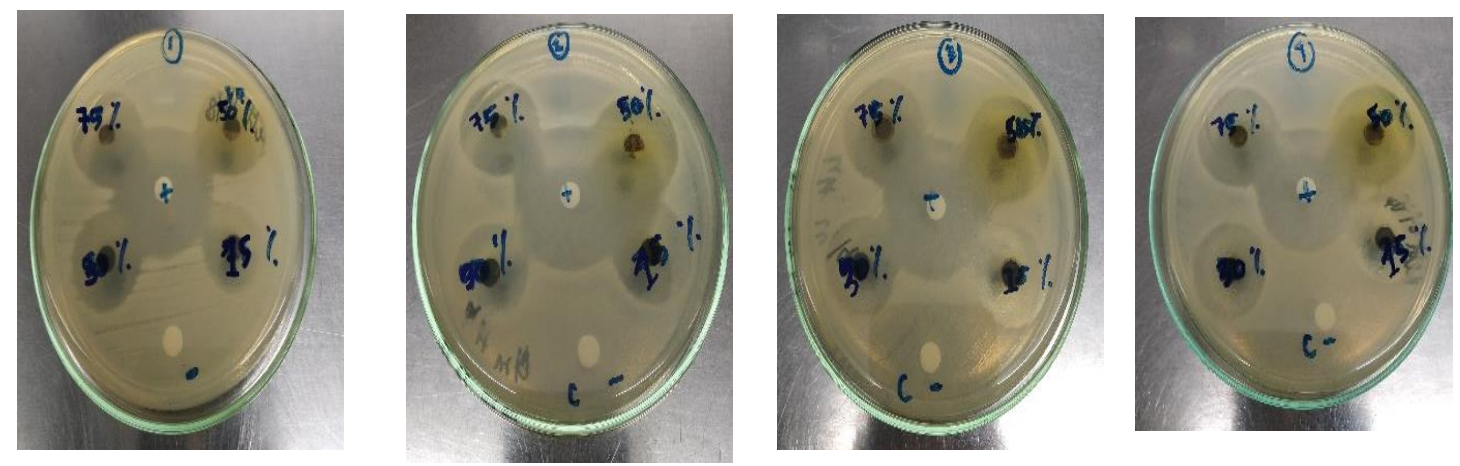

Gambar 2. Hasil Zona Hambat Pengulangan ke-1, 2, 3, dan 4.

Berdasarkan Tabel 3 dan Gambar 2. Menunjukkan bahwa Diameter terbesar yang dihasilkan oleh senyawa tanin terdapat pada konsentrasi $75 \%$ yang memiliki rata-rata zona hambat dalam 4 kali pengulangan sebesar 21.78 mm yang masuk dalam kategori respon hambat sangat kuat yaitu $>20 \mathrm{~mm}$, sedangkan pada konsentrasi $15 \%, 30 \%$, dan $50 \%$ memiliki rata-rata zona hambat berturut-turut sebesar 15,03 mm, 16,78 $\mathrm{mm}, 19,02 \mathrm{~mm}$ yang masuk dalam kategori kuat berdasarkan klasifikasi (Davis dan Stout, 1971). Sementara pada penelitian Ariani (2016), diameter terbesar yang dihasilkan oleh ekstrak daun mimba yaitu sebesar $18.25 \mathrm{~mm}$ dan masuk dalam kategori respon hambat kuat yaitu 10-20 mm berdasarkan klasifikasi (Davis dan Stout, 2009).

Penggunaan kontrol positif berupa Amoxcillin dipilih karena memiliki spektrum yang luas dan sangat sensitif terhadap bakteri gram positif dan gram negatif karena dapat menghambat pertumbuhan bakteri dengan mengganggu sintesis dinding sel bakteri. 
Dinding sel merupakan lapisan luar yang melindungi inti sel pada setiap spesies bakteri. Dengan terhambatnya reaksi tersebut maka akan mengakibatkan sintesis peptidoglikan berhenti dan bakteri pun akan mati (Katzung, 2007)

Dinding sel bakteri gram negatif mempunyai kandungan lipid yang tinggi yang terletak pada membran luar yaitu polisakarida dan lipid ini akan larut dengan alkohol, sehingga pori-pori dinding sel akan membesar dan merusak permeabilitas membrane (Waidil, 2014). Bakteri membutuhkan nutrisi salah satunya air untuk bertahan hidup, Karena tanin merupakan senyawa yang dapat larut dengan air sehingga akan mudah masuk ke dalam porin yang merupakan pintu masuk dan keluarnya nutrisi yang dibutuhkan oleh bakteri (Darsana, 2018)

Setelah tanin masuk ke dalam dinding sel melalui porin, tanin dengan mudahnya menembus dinding sel bagian luar yaitu lipopolisakarida. Dengan rusaknya permeabilitas dinding sel, maka senyawa tanin akan masuk ke dalam peptidoglikan yang berperan penting dalam mempertahankan kehidupan bakteri dari lingkungan yang hipotonik sehingga kehilangan dan kerusakan dinding sel ini menyebabkan hilangnya kekakuan dinding sel dan akan menghambat proses keluar masuknya nutrisi yang dibutuhkan bakteri sehingga berakibat pada kematian sel (Rachmawaty, 2009). Setelah senyawa tanin masuk ke dalam sel melewati dinding sel, tanin akan menghambat sintesis protein yang terjadi di dalam ribosom. Tanin akan mengganggu fungsi ribosom untuk mentranslate RNA menjadi protein sehingga protein tidak bisa disintesis (Radji, 2011). Translasi RNA adalah proses yang terjadi di ribosom yang terletak pada sitoplasma yang berfungsi untuk mensintesis protein setelah terjadinya proses transkripsi DNA menjadi RNA di dalam inti sel. Proses translasi memiliki beberapa fase yaitu inisiasi, perpanjangan, dan pemutusan, Senyawa tanin akan mengganggu fungsi ribosom dalam fase perpanjangan yang akan menyebabkan ribosom salah menerjemahkan kode genetik yang dibawa oleh RNA sehingga tidak dapat terbentuk protein dan akan mengakibatkan kematian pada bakteri (Sari, 2011) Berdasarkan mekanisme kerja senyawa tanin terhadap bakteri Salmonella typhi maka, senyawa tanin dari daun mimba (Azzadirachta indica) dapat mengakibatkan efek menghambat (Bakteriostatik) dan juga membunuh bakteri (Bakteriosidal) (Madigan, 2003)

\section{Kesimpulan}

Berdasarkan hasil penelitian disimpulkan bahwa senyawa tanin ekstrak daun mimba (Azzadirachta indica) memiliki aktivitas antibakteri dengan rentang klasifikasi kuat sampai sangat kuat berdasarkan klasifikasi Davis \& Stout. Zona hambat pada konsentrasi 15\%, 30\%, 50\%, 75\% berturut-turut adalah $15.03 \mathrm{~mm}, 16.78$ $\mathrm{mm}, 19.02 \mathrm{~mm}, 21.78 \mathrm{~mm}, 28.02 \mathrm{~mm}$.

\section{Daftar Pustaka}

Davis WW, Stout TR. 2009. Disc Plate Method of Microbiological Antibiotic Assay. Applied Microbiology 22(4): 659-665.

Darsana, I.G.O., Besung, I.N.K., dan Mahatmi, H. 2012. Potensi daun Binahong (Anredera cordifolia (Tenore) Steenis) Dalam Menghambat Pertumbuhan bakteri Escherichia coli secara In Vitro. J. Indonesia Medicus Veterinus, 1 (3) ; 337-351.

Dewi I, Astuti KW, Warditiani, N.K., 2013. Skrining fitokimia ekstrak etanol 95\% kulit buah manggis (Garcinia mangostana L). Jurnal Farmasi Udayana. 
Dyah Dkk, 2016, Identifikasi kandungan senyawa fitokimia minyak mimba (Azzadirachta indica), Jurnal Biologi, Vol.5(3): 5.

Erni, Y, Mahtuti. 2004. Pengaruh Daya Antimikroba Asam Tanat Terhadap Pertumbuhan Bakteri Salmonella Typhi Secara In Vitro. Universitas Airlangga Surabaya.

Guyton, Arthur. C. 2007. Buku Ajar Fisiologi Kedokteran. EGC : Jakarta.

Horvart, P. J. 1981. The Nutrional and Eculogical Significance of Acer Tanins and Related Polyphenols. Thesis. New York.

Katzung, B,G. 2007. Basic and Clinical Pharmacology. Farmakologi Dasar dan Klinik. Edisi ke-10, Salemba Medika. Jakarta.

Madigan, M. T. Martinko, J. M. dan Parker, J. 2003. Brock Biology of Microorganism. Southern Illinois University Carbondale : Illinois.

Mihra,. Minarmi, R.J., Purnama Ningsih., 2018. Analisis Kadar Tanin Dalam Ekstrak Daun Mimba (Azzadirachta Indica A.Juss) Dengan Pelarut Air Dan Etanol. Jurnal Akademika Kim, Vol. 7 (4): 179-184.

Moeloek, F. A. 2006. Herbal and Traditional Medicine : National Perspectives And Policies In Indonesia. Jurnal Bahan Alam Indonesia. 5 (1) 293-297.

Putu, P.S. Wiwik, S. R. Ni, M. P. 2015. Identifikasi dan Uji Aktivitas Senyawa Tanin dari Ekstrak Daun Trembesi (Samanea saman (Jacq.) Merr) sebagai Antibakteri Escherichia coli (E. coli). Jurnal Kimia 9 (1) : 27-34.

Rachmawaty, Farida Juliantina et al. 2009. Manfaat Sirih Merah (Piper crocatum) Sebagai Agen Anti Bakterial Terhadap Bakteri Gram
Positif dan Negatif. Jurnal Kedokteran dan Kesehatan Indonesia.

Radji, Maksum. 2011. Buku Ajar Mikrobiologi : Panduan Mahasiswa Farmasi dan Kedokteran, Jakarta: EGC, pp.1012, 179-199.

Rohma, A, 2011, Uji Aktivitas Antibakteri Ekstrak Daun Mimba ( Azzadirachta indica A. juss) terhadap Bakteri Shigella dysentriae, Tidak Diterbitkan, Malang: Akademi Analis Farmasi dan Makanan Putra Indonesia Malang.

Sari, F.P. dan S. M. Sari. 2011. Ekstraksi Zat Aktif Antimikroba dari Tanaman Yodium (Jatropha multifida Linn) sebgai Bahan Baku Alternatif Antibiotik Alami. Fakultas Teknik Universitas Diponegoro. Semarang.

Senja, Yulia Rima, dkk. 2014. Perbandingan metode ekstraksi dan variasi pelarut terhadap rendeman dan aktivitas antioksidan ekstrak kubis ungu (Brassica oleracea L. var. capitata f. rubra). Journal of Faculty of Pharmacy Universitas Gadjah Mada, Vol 19 (1), 43-48.

Sugiharjo, 2007. The difference of antibacterial effect of neem leaves and stick extracts. International Chin Journal dental, Vol.7: 27-29.

Susmitha, S. Vidyamol, KK. Ranganayaki, P. 2013. Phytochemical extraction and antimicrobial properties of Azadirachta indica (neem). Global Journal of Pharmacology.

Tri Atmodjo, $\mathrm{P}$ dan Triningsih, E.M. Besarnya Kasus Demam Tifoid di Indonesia dan Pola Resisten Salmonella Typhi Terhadap Antibiotika. Majalah Kesehatan 
Masyarakat Indonesia. 5:261-263.

1998.

Waidil Anuar,. Andi, D. Christine, J.

2014. Isolasi Bakteri Selulolitik dari Perairan Dumai. JOM FMIPA Vol.1 (2) 